\title{
Low expression of RECQL is associated with poor prognosis in Chinese breast cancer patients
}

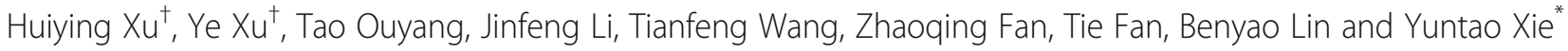

\begin{abstract}
Background: RECQL is a number of the RecQ DNA helicase family and plays an important role in maintaining genome stability. Although several studies have reported that RECQL mutations were correlated with the susceptibility to breast cancer, the effect on prognosis in breast cancer was not yet clarified. Here, we explored the association between RECQL expression level and survival in patients with breast cancer.
\end{abstract}

Methods: In the first cohort, the RECQL mRNA expression level was evaluated in 774 primary breast cancer patients using a quantitative real-time PCR assay. Then, in the second independent cohort, the level of RECQL protein expression was detected in 322 patients with breast cancer using immunohistochemistry assay. Survival curves of patients with RECQL expression were compared using the Kaplan-Meier method with log-rank test.

Results: In the first cohort of 774 breast cancer patients, the low expression level of RECQL mRNA was significantly correlated with aggressive clinicopathological characteristics, including the positive lymph node status $(P=0.026)$, HER2 overexpression $(P<0.001)$, ER negative status $(P=0.047)$ and high tumor grade $(P=0.041)$. Moreover, the low expression level of RECQL mRNA was significantly associated with poor distant recurrence-free survival (DRFS, unadjusted hazard ratio (HR): 2.77, 95\% confidence interval (CI): 1.88-4.09, $P<0.001$ ) and disease-specific survival (DSS, unadjusted HR: $3.10,95 \% \mathrm{Cl}: 1.84-5.20, P<0.001$ ), and it remained an independent unfavorable factor for DRFS and DSS (DRFS: adjusted HR: 3.04, 95\% Cl: 1.89-4.87, $P<0.001$; DSS: adjusted HR: 4.25, 95\% Cl: 2.12-8.46, $P<0.001$ ). In the second cohort of 322 breast cancer patients, low expression of RECQL protein was also subject to poor survival in breast cancer, and it was an independent prognosis factor of poor DRFS by multivariate analysis (DRFS: adjusted HR: 2.12, 95\% Cl: 1.16-3.88, $P=0.015)$.

Conclusions: Breast cancer patients with low RECQL expression had a worse survival. The expression level of RECQL may be a potential prognosis factor for breast cancer.

Keywords: RECQL, Expression, Survival, Breast cancer

\section{Background}

At present, breast cancer was one of the most prevalent cancers among women in the world, and seriously threatened the health of women [1]. Because of the biological heterogeneity of breast cancer, defining accurate prognostic and predictive biomarkers may be in favor of designing effective treatments for breast cancer patients [2].

\footnotetext{
* Correspondence: zlxyt2@bjmu.edu.cn

${ }^{\dagger}$ Huiying Xu and Ye Xu contributed equally to this work.

Key Laboratory of Carcinogenesis and Translational Research (Ministry of

Education), Breast Center, Beijing Cancer Hospital \& Institute, Peking

University Cancer Hospital, Beijing 100142, People's Republic of China
}

RECQL is an ATP-dependent DNA helicase enzyme, which belongs to the family of RecQ helicase that plays an important role in mismatch repair, nucleotide excision repair and direct repair [3, 4]. RecQ helicase in human includes five members, namely RECQL, BLM, WRN, RECQL4 and RECQL5. Previous studies showed that the germline mutations in BLM, WRN and RECQL4 had high predisposition to cancer and premature aging [3, 4]. RECQL is the most abundant DNA helicase enzyme among RecQ helicase family and also has critical biological functions. RECQL has been shown to involve in DNA replication [5, 6], transcription [7], recombination [8] and repair $[9,10]$, restart stalled

(c) The Author(s). 2018 Open Access This article is distributed under the terms of the Creative Commons Attribution 4.0 International License (http://creativecommons.org/licenses/by/4.0/), which permits unrestricted use, distribution, and 
Table 1 Association between RECQL mRNA Expression and Clinicopathologic Characteristics $(N=774)$

\begin{tabular}{|c|c|c|c|c|c|c|}
\hline \multirow[t]{3}{*}{ Characteristic } & \multirow[t]{3}{*}{ No. } & \multicolumn{4}{|c|}{ RECQL mRNA expression } & \multirow[t]{3}{*}{$P$} \\
\hline & & \multicolumn{2}{|l|}{ Low } & \multicolumn{2}{|l|}{ High } & \\
\hline & & No. & $\%$ & No. & $\%$ & \\
\hline Total & 774 & 387 & 50.0 & 387 & 50.0 & \\
\hline \multicolumn{7}{|l|}{ Age } \\
\hline$\leq 50 \mathrm{yr}$ & 331 & 168 & 43.4 & 163 & 42.1 & \multirow[t]{2}{*}{0.72} \\
\hline$>50 \mathrm{yr}$ & 443 & 219 & 56.6 & 224 & 57.9 & \\
\hline \multicolumn{7}{|l|}{ Tumor size } \\
\hline$\leq 2 \mathrm{~cm}$ & 298 & 142 & 36.7 & 156 & 40.3 & \multirow[t]{2}{*}{0.30} \\
\hline$>2 \mathrm{~cm}$ & 476 & 245 & 63.3 & 231 & 59.7 & \\
\hline \multicolumn{7}{|l|}{ Tumor grade } \\
\hline । & 186 & 85 & 22.7 & 101 & 26.6 & \multirow[t]{4}{*}{0.041} \\
\hline$\|$ & 443 & 215 & 57.5 & 228 & 60.2 & \\
\hline III & 124 & 74 & 19.8 & 50 & 13.2 & \\
\hline Unknown & 21 & 13 & & 8 & & \\
\hline \multicolumn{7}{|l|}{ Lymph node status } \\
\hline Negative & 510 & 239 & 65.5 & 271 & 73.0 & \multirow[t]{3}{*}{0.026} \\
\hline Positive & 226 & 126 & 34.5 & 100 & 27.0 & \\
\hline Unknown & 38 & 22 & & 16 & & \\
\hline \multicolumn{7}{|l|}{ ER status } \\
\hline Negative & 223 & 124 & 32.1 & 99 & 25.6 & \multirow[t]{3}{*}{0.047} \\
\hline Positive & 549 & 262 & 67.9 & 287 & 74.4 & \\
\hline Unknown & 2 & 1 & & 1 & & \\
\hline \multicolumn{7}{|l|}{ PR status } \\
\hline Negative & 302 & 160 & 42.0 & 142 & 37.1 & \multirow[t]{3}{*}{0.16} \\
\hline Positive & 462 & 221 & 58.0 & 241 & 62.9 & \\
\hline Unknown & 10 & 6 & & 4 & & \\
\hline \multicolumn{7}{|l|}{ HER2 status } \\
\hline Negative & 556 & 254 & 66.0 & 302 & 78.2 & \multirow[t]{3}{*}{$<0.001$} \\
\hline Positive & 215 & 131 & 34.0 & 84 & 21.8 & \\
\hline Unknown & 3 & 2 & & 1 & & \\
\hline \multicolumn{7}{|l|}{ Ki-67 } \\
\hline High & 445 & 233 & 62.3 & 212 & 55.9 & \multirow[t]{3}{*}{0.08} \\
\hline Low & 308 & 141 & 37.7 & 167 & 44.1 & \\
\hline Unknown & 21 & 13 & & 8 & & \\
\hline \multicolumn{7}{|l|}{ Subtype } \\
\hline Luminal A & 173 & 76 & 19.8 & 97 & 25.1 & \multirow[t]{6}{*}{0.003} \\
\hline Luminal B(HER2-) & 268 & 119 & 30.1 & 149 & 38.6 & \\
\hline Luminal $B($ HER2 +$)$ & 123 & 78 & 20.3 & 45 & 11.7 & \\
\hline HER2+ & 92 & 53 & 13.8 & 39 & 10.1 & \\
\hline $\mathrm{TN}$ & 114 & 58 & 15.1 & 56 & 14.5 & \\
\hline Unknown & 4 & 3 & & 1 & & \\
\hline Adjuvant Therapy & & & & & & \\
\hline$C$ & 157 & 83 & 21.4 & 74 & 19.1 & 0.011 \\
\hline
\end{tabular}

Table 1 Association between RECQL mRNA Expression and Clinicopathologic Characteristics $(N=774)$ (Continued)

\begin{tabular}{|c|c|c|c|c|c|c|}
\hline \multirow[t]{3}{*}{ Characteristic } & \multirow[t]{3}{*}{ No. } & \multicolumn{4}{|c|}{ RECQL mRNA expression } & \multirow[t]{3}{*}{$P$} \\
\hline & & \multicolumn{2}{|l|}{ Low } & \multicolumn{2}{|c|}{ High } & \\
\hline & & No. & $\%$ & No. & $\%$ & \\
\hline E & 281 & 121 & 31.3 & 160 & 41.3 & \\
\hline$C+E$ & 245 & 127 & 32.8 & 118 & 30.5 & \\
\hline No therapy & 91 & 56 & 14.5 & 35 & 9.0 & \\
\hline \multicolumn{7}{|l|}{ Trastuzumab use } \\
\hline No & 739 & 372 & 96.1 & 367 & 94.8 & 0.39 \\
\hline Yes & 35 & 15 & 3.9 & 20 & 5.2 & \\
\hline \multicolumn{7}{|l|}{ Surgery type } \\
\hline BCS & 294 & 137 & 37.4 & 157 & 42.1 & 0.20 \\
\hline Mastectomy & 445 & 229 & 62.6 & 216 & 57.9 & \\
\hline Unknown & 35 & 21 & & 14 & & \\
\hline
\end{tabular}

Abbreviations: ER, estrogen receptor; PR, progesterone receptor; HER2, human epidermal growth factor receptor-2; TN, triple negative; $C$, chemotherapy; $E$, endocrinotherapy; $\mathrm{C}+\mathrm{E}$, chemotherapy and endocrinotherapy; BCS, breast-conserving surgery

Comments: luminal A: ER+ or PR $\geq 20 \%$, HER2-, Ki-67 $<14 \%$; luminal B (HER2-): ER+ and HER2-, Ki-67 $\geq 14 \%$ or PR- $/<20 \%$, luminal B (HER2+): ER+ and HER2+; HER2(+): ER- and PR-, HER2+; TN: ER- and PR-, HER2-

replication forks [11-13], and telomere maintenance [14]. Compared with wild-type mice, mice with deficient RECQL hadn't any apparent phenotypic differences, but embryonic fibroblasts from RECQL-deficient mice exhibited many signs of genomic instability, such as aneuploidy, spontaneous, chromosomal breakage and frequent translocation events [15]. Besides, human RECQL-deficient cells turned out to be chromosomal instability, and hypersensitive to ionizing radiation $[10,15]$. These results indicated that RECQL played an important role in maintaining genomic stability.

Previously, our lab and Cybulski et al. reported that RECQL gene mutations were correlated with high risk of breast cancer independently in Chinese [16] and Caucasian populations [17]. Kwong et al. also found six germline mutations in RECQL gene in 1110 patients with high risk breast cancer in Hong Kong [18]. At present, RECQL was demonstrated as a moderate breast cancer susceptibility gene and a tumor suppressor. Earlier studies revealed that single nucleotide polymorphisms of RECQL affected clinical prognosis of patients with pancreatic cancer $[19,20]$. Nevertheless, few studies were performed on the specific effect of RECQL expression on breast cancer outcomes. In this study, we investigated the association between RECQL mRNA and protein expression and survival of breast cancer in two independent cohorts.

\section{Methods}

Study population

In the first cohort, the study samples were pretreatment core-needle biopsy specimens of 834 primary breast cancer patients (stage I-III) who were treated at the Breast Center, 
Peking University Cancer Hospital from 2004 to 2011. Of these, 60 specimens failed to assess the level of RECQL mRNA expression due to the poor quality of the RNA samples. Thus, a total of 774 breast cancer patients were analyzed in the first cohort. The patients' age at diagnosis ranged from 25 to 93 years, whose median was 52 years. According to medical records, patients received either a mastectomy $(n=445)$ or a breast-conserving surgery $(n=$ 294). The majority of patients received adjuvant therapy, including chemotherapy, endocrine therapy, or chemotherapy in combination with endocrine therapy. Thirty-five patients received adjuvant trastuzumab therapy (Table 1). The median follow-up of all 774 patients was 82 months (range 2 to 140 months). During follow-up period, 150 patients experienced distant recurrences or died of the disease.

To further clarify the conformance to the results of the first cohort, we analyzed another independent cohort of patients in this study (cohort 2). In cohort 2, paraffin blocks of tumor tissues were available for 358 primary breast cancer patients (stage I-III) who were treated at Breast Center, Peking University Cancer Hospital from January 2001 to June 2002. Among these, 18 patients lost the follow-up, and 18 tumor specimens were failed to assess RECQL staining because of tissue loss during the experiment. Finally, 322 patients were analyzed in cohort 2. The mean patients' age was 50 years (range 25 to 88 years), and the median follow-up of these patients was 98 months (range 2 to 129 months). All patients received modified radical mastectomy surgery. The majority of patients $(90.4 \%, 291 / 322)$ received adjuvant therapy after surgery. None of them received adjuvant trastuzumab therapy (Table 2).

The tumor size, grade, and stage were classified as same as our previous study [21]. This study was approved by the Research and Ethical Committee of Peking University Cancer Hospital.

\section{Pathology}

These breast cancer tissues were obtained by the core-needle biopsy, estrogen receptor (ER), progesterone receptor (PR), and human epidermal growth factor receptor 2 (HER2) were determined by an immunohistochemical (IHC) assay as described previously [21]. In the present study, ER or PR was considered positive when it had $\geq 1 \%$ positive nuclear staining tumor cells. HER2 was deemed to be positive when its immunohistochemical score was $3+$ or the fluorescence in situ hybridization assay showed HER2 gene amplification [22].

\section{RECQL mRNA expression analysis by real-time quantitative PCR}

In cohort 1, breast tumor RNA extracting and then transcribing RNA to cDNA were done according to the manufacturer's instructions as described previously [23].
Table 2 Association between RECQL Protein Expression and Clinicopathologic Characteristic ( $\mathrm{N}=322)$

\begin{tabular}{|c|c|c|c|c|c|c|}
\hline \multirow[t]{3}{*}{ Characteristic } & \multirow[t]{3}{*}{ No. } & \multicolumn{3}{|c|}{ RECQL protein expression } & & \multirow{3}{*}{$\mathrm{p}$} \\
\hline & & \multicolumn{2}{|l|}{ Low } & \multicolumn{2}{|l|}{ High } & \\
\hline & & No. & $\%$ & No. & $\%$ & \\
\hline Total & 322 & 133 & 41.3 & 189 & 58.7 & \\
\hline \multicolumn{7}{|l|}{ Age } \\
\hline$\leq 50 \mathrm{yr}$ & 153 & 74 & 54.4 & 82 & 43.4 & \multirow[t]{2}{*}{0.07} \\
\hline$>50 \mathrm{yr}$ & 169 & 62 & 45.6 & 107 & 56.6 & \\
\hline \multicolumn{7}{|l|}{ Tumor size } \\
\hline$\leq 2 \mathrm{~cm}$ & 112 & 48 & 45.7 & 64 & 43.5 & \multirow[t]{3}{*}{0.73} \\
\hline$>2 \mathrm{~cm}$ & 140 & 57 & 54.3 & 83 & 56.5 & \\
\hline Unknown & 70 & 28 & & 42 & & \\
\hline \multicolumn{7}{|c|}{ Lymph node status } \\
\hline Negative & 168 & 75 & 59.1 & 93 & 51.1 & \multirow[t]{3}{*}{0.17} \\
\hline Positive & 141 & 52 & 40.9 & 89 & 48.9 & \\
\hline Unknown & 13 & 6 & & 7 & & \\
\hline \multicolumn{7}{|l|}{ ER status } \\
\hline Negative & 100 & 44 & 43.6 & 56 & 35.9 & \multirow[t]{3}{*}{0.22} \\
\hline Positive & 157 & 57 & 56.4 & 100 & 64.1 & \\
\hline Unknown & 65 & 30 & & 33 & & \\
\hline \multicolumn{7}{|l|}{ PR status } \\
\hline Negative & 101 & 33 & 33.3 & 68 & 43.3 & \multirow[t]{3}{*}{0.11} \\
\hline Positive & 155 & 66 & 66.7 & 89 & 56.7 & \\
\hline Unknown & 66 & 34 & & 32 & & \\
\hline \multicolumn{7}{|l|}{ HER2 status } \\
\hline Negative & 233 & 98 & 78.4 & 135 & 78.0 & \multirow[t]{3}{*}{0.94} \\
\hline Positive & 65 & 27 & 21.6 & 38 & 22.0 & \\
\hline Unknown & 24 & 8 & & 16 & & \\
\hline \multicolumn{7}{|l|}{ TN } \\
\hline Yes & 29 & 7 & 7.8 & 22 & 14.8 & \multirow[t]{3}{*}{0.19} \\
\hline No & 210 & 83 & 92.2 & 127 & 85.2 & \\
\hline Unknown & 83 & 43 & & 40 & & \\
\hline \multicolumn{7}{|c|}{ Adjuvant Therapy } \\
\hline C & 124 & 58 & 43.6 & 66 & 34.9 & \multirow[t]{4}{*}{0.463} \\
\hline E & 20 & 7 & 5.3 & 13 & 6.9 & \\
\hline$C+E$ & 147 & 56 & 42.1 & 91 & 48.1 & \\
\hline No therapy & 31 & 12 & 9.0 & 19 & 10.1 & \\
\hline
\end{tabular}

Abbreviations: ER, estrogen receptor; PR, progesterone receptor; HER2, human epidermal growth factor receptor-2; TN, triple negative; $C$, chemotherapy; $E$, endocrinotherapy; $C+E$, chemotherapy and endocrinotherapy

Real-time PCR of the RECQL gene was performed as described previously [23]. The primers for target gene RECQL were as follow: 5'- ACAAAATGTGCGATAA CTGCTG-3' and 5'-GCACCCTTTCCCATCCAAGA-3'. The sequences of the primers for endogenous control $\beta$-actin were 5'-GACAGGATGCAGAAGGAGATCAC 
T-3' and 5'-GTCAAGAAAGGGTGTAACGCAACT-3'. The PCR conditions were: $95{ }^{\circ} \mathrm{C}$ for $5 \mathrm{~min}$ followed by 40 cycles of $95{ }^{\circ} \mathrm{C}$ for $5 \mathrm{~s}, 60^{\circ} \mathrm{C}$ for $30 \mathrm{~s}$ and final stage was followed by a melting curve from $60{ }^{\circ} \mathrm{C}$ to $95{ }^{\circ} \mathrm{C}$. Each sample was assayed in triplicate with RNase-free water as negative control. Relative RECQL mRNA expression quantifications were calculated according to the formula $2^{-\Delta \Delta \mathrm{Ct}}$. In the experiment, $\beta$-actin was an endogenous control and 293 cell line RNA control was a calibrator in each plate. The result showed the mean amplification efficiency of RECQL is $97 \%$ and $\beta$-actin's is $94 \%$. A melting curve analysis was completed to confirm the specificity of amplification in the each run.

Median of the relative gene expression values was selected as cutoff value to estimate the level of RECQL expression. Patients whose relative gene expression values were above the cutoff value were considered to be high expression of RECQL mRNA, while the rest of patients were low expression. Therefore, the 774 patients were divided into the high mRNA expression group $(n=387)$ and the low mRNA expression group $(n=387)$.

\section{RECQL protein expression analysis by immunohistochemical assay}

In cohort 2 , the tumor section ( $4 \mu \mathrm{m}$ thick) was used for immunohistochemical staining. At first, tissue slides were dewaxed twice with xylene, then rehydrated through a graded alcohol series and immersed for $20 \mathrm{~min}$ in a $3 \%$ hydrogen peroxide buffer. After $\mathrm{ddH}_{2} \mathrm{O}$ rinsing, the tissue slides were putted into a box filled with EDTA buffer (pH 9.0) and then putted the box into a water bath at $95{ }^{\circ} \mathrm{C}$ for $25 \mathrm{~min}$ to retrieve antigen. The tissue slides were washed with $1 \times$ PBS for $5 \mathrm{~min}$, blocked with normal goat serum for $30 \mathrm{~min}$, and then incubated overnight at $4{ }^{\circ} \mathrm{C}$ in a humidified chamber with the primary anti-RECQL antibody (Bethyl
Laboratories, catalog No.A300-450A) at a dilution of 1:2000. The sections were rinsed three times with $1 \times$ PBS and incubated with secondary antibody (ZSGB-BIO, catalog No.PV-6000) at room temperature for $60 \mathrm{~min}$. The sections were $\mathrm{DAB}$ development and counterstained with hematoxylin. Negative controls were concluded each run to ensure that all the staining was specific.

The staining intensity in the nuclear and staining percentage of tumor cells were both evaluated: no staining was given a score 0 ; a faint, moderate or strong staining was scored as 1 , 2or 3, respectively. The staining percentage of tumor cells was estimated (0-100\%). When the value calculated by multiplication of the staining intensity and staining percentage was more than $100 \%$, the tumor specimen was regarded as RECQL protein expression high. Each immunostained slide was evaluated by two blinded independent pathologists. Re-examinations were conducted when evaluations were discrepancies.

\section{Statistical analysis}

The Pearson's $x^{2}$ test was used to analyze the associations between the expression level of RECQL and clinicopathological features. For the survival analyses, distant recurrence-free survival (DRFS) was defined as the time from the date of diagnosis to the first distant recurrence or the occurrence of breast cancer related-death without a recorded relapse. Disease-specific survival (DSS) was defined as the time from date of diagnosis to the occurrence of death where breast cancer was the primary or underlying cause of death. Survival curve was performed using the Kaplan-Meier method with the log-rank test. A Cox regression model was performed in multivariate analysis. A $P$ value $<0.05$ with a two-sided was considered significant statistically. The SPSS Statistics 20.0 software (Chicago, USA) was used to analyze all data in the study.

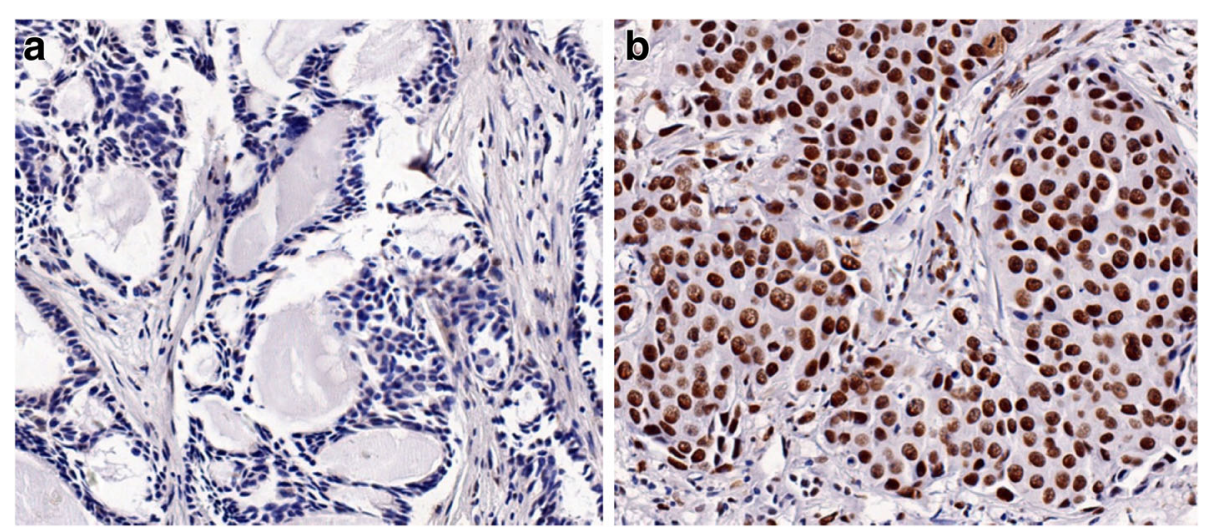

Fig. 1 Immunohistochemical staining for RECQL expression in breast cancers. RECQL showed a negative staining and $\mathbf{b}$ positive staining (magnification $\times 200$ ) 


\section{Results}

\section{Clinicopathologic characteristics}

In cohort 1, RECQL mRNA expression was measured successfully in 774 patients. Totally, 387 patients (50\%) exhibited high level of RECQL mRNA expression and the remaining $50 \%$ of tumors exhibited low expression of RECQL mRNA based on the median as cut-off value. According to the clinicopathological characteristics showed in Table 1, patients with low RECQL mRNA expression tend to be lymph node-positive (34.5\% vs. $27.0 \%$, $P=0.026)$, tumor grade III $(19.8 \%$ vs. $13.2 \%, P=0.041)$,
HER2-positive (34.0\% vs. $21.8 \%, P<0.001$ ), ER-negative (32.1\% vs. $25.6 \%, P=0.047)$, and Luminal B (HER $2+)$ subtype $(P=0.003)$ (Table 1$)$. However, the expression level of RECQL mRNA was not associated with diagnosis age, tumor size, and PR status (Table 1).

In the cohort 2, RECQL is mainly expressed in the cell nucleus (Fig. 1). Among 322 patients, 189 (58.7\%) patients exhibited high level of RECQL protein expression and the remaining 133 (41.3\%) patients exhibited low expression of RECQL protein expression. In this cohort, there was no correlation between RECQL protein

a

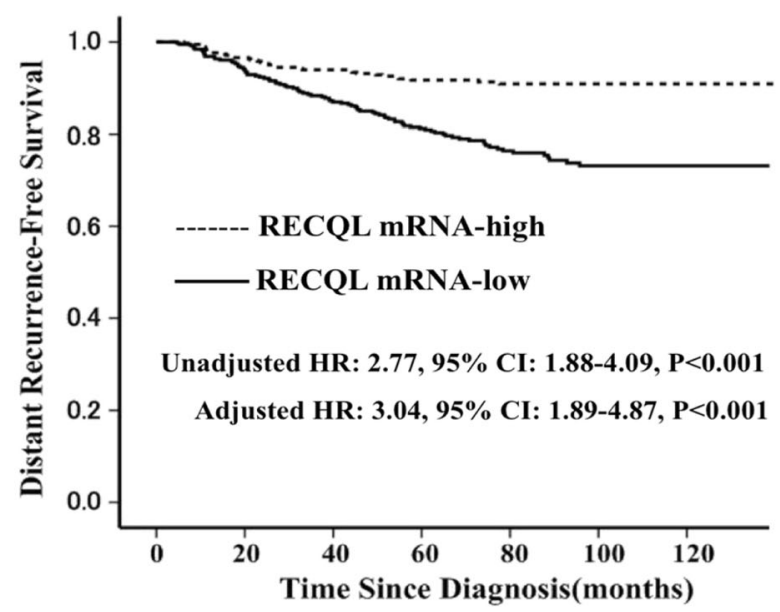

\begin{tabular}{|c|c|c|c|c|c|c|c|}
\hline $\begin{array}{r}\text { No. at risk } \\
\text { RECQL mRNA-high }\end{array}$ & 387 & 366 & 347 & 308 & 193 & 63 & 8 \\
\hline RECQL mRNA-low & 387 & 354 & 313 & 273 & 185 & 99 & 36 \\
\hline
\end{tabular}

b

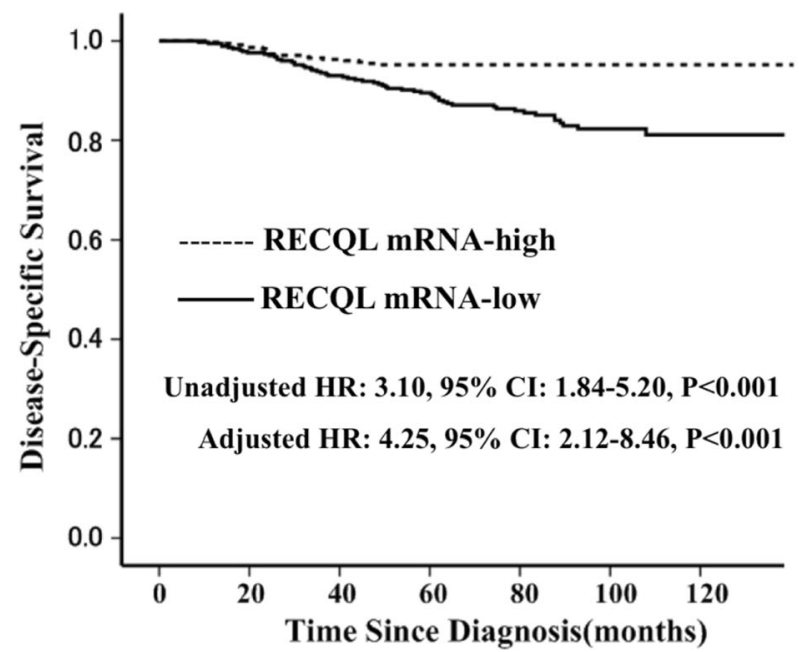

No. at risk

RECQL mRNA-high

$\begin{array}{lllllll}387 & 374 & 355 & 320 & 200 & 65 & 10\end{array}$

Fig. 2 Comparison of the prognosis between RECQL mRNA expression high and low patients in the first cohort $(n=774)$ using Kaplan-Meier method. There was significant difference in distant recurrence-free survival (a) and disease-specific survival (b) between RECQL mRNA expression high and low patients 
expression and tumor size, age of diagnosis, ER, PR and HER2 status, and lymph nodes status (Table 2).

\section{RECQL mRNA expression associated with survival in cohort 1}

In cohort 1, 774 patients were qualified for research and being analyzed. The median follow-up was 82 months (range 2 to 140 months) in cohort 1 . The 10-year DRFS and DSS rates in 774 patients were $81.7 \%$ (95\% confidence interval (CI): $78.6-84.8 \%)$, and $87.6 \%$ (95\% CI: 84.5-90.7\%), respectively.

RECQL mRNA expression was significantly associated with survival in cohort 1 with 774 patients. Patients $(n=387)$ with low expression of RECQL mRNA had a significantly worse DRFS and DSS than did those with high level (DRFS, unadjusted HR: 2.77, 95\% CI: $1.88-4.09, P<0.001$; DSS: unadjusted HR: 3.10, 95\% CI: 1.84-5.20, $P<0.001$ ) (Fig. 2a-b). Moreover, multivariate analysis revealed that low level expression of RECQL mRNA was an independent unfavorable factor for DRFS and DSS (DRFS: adjusted HR: 3.04, 95\% CI: 1.89-4.87, $P<0.001$; DSS: adjusted HR: 4.25, 95\% CI: 2.12-8.46, $P<0.001$ ) in these 774 patients after adjustment for tumor size, diagnosis age, ER status, PR status, HER2 status, histological grade, lymph node status and adjuvant therapy (Table 3). Lymph node positive was also independent unfavorable factor for DRFS $(P<0.001)$ and DSS $(P<0.001)$ (Table 3$)$.

These 774 patients with breast cancer were further divided into five different subtypes according to ER $\backslash P R \backslash H E R 2 \backslash K i-67$ status, and then survival analyses were performed in each subtype. The results showed that patients with RECQL mRNA low expression had worse survival compared with those with high expression in the luminal A, luminal B (HER2-), luminal B (HER2+) and the triple negative subtype (Additional file 1: Figure S1 A-D). However, in the HER2+ subtype, there was no significant difference between patients expressed high RECQL mRNA and low (Additional file 1: Figure S1E).

\section{RECQL protein expression associated with survival in cohort 2}

The results from the cohort 1 showed that RECQL mRNA expression level was significantly associated with survival of breast cancer patients. To verify the finding in protein level, another independent cohort of 322 breast cancer patients (I-III stage) was included for analysis. The median follow-up was

Table 3 Multivariate Analyses of Survival in the First Study Population ( $N=774)$

\begin{tabular}{|c|c|c|c|c|c|c|}
\hline \multirow[t]{2}{*}{ Variable } & \multicolumn{3}{|l|}{ DRFS } & \multicolumn{3}{|l|}{ DSS } \\
\hline & $\mathrm{HR}$ & $95 \% \mathrm{Cl}$ & $P$ & $\mathrm{HR}$ & $95 \% \mathrm{Cl}$ & $P$ \\
\hline \multicolumn{7}{|l|}{ Age } \\
\hline$\leq 50 \mathrm{yr} . \mathrm{vs} .>50 \mathrm{yr}$ & 0.84 & $0.56-1.26$ & 0.40 & 0.63 & $0.36-1.10$ & 0.10 \\
\hline \multicolumn{7}{|l|}{ ER status } \\
\hline Negative vs. Positive & 1.93 & $0.98-3.79$ & 0.06 & 1.51 & $0.62-3.72$ & 0.37 \\
\hline \multicolumn{7}{|l|}{ PR status } \\
\hline Negative vs. Positive & 1.32 & $0.77-2.25$ & 0.31 & 2.13 & $1.09-4.15$ & 0.027 \\
\hline \multicolumn{7}{|l|}{ HER2 status } \\
\hline Positive vs. Negative & 0.88 & $0.56-1.39$ & 0.59 & 0.75 & $0.42-1.36$ & 0.34 \\
\hline \multicolumn{7}{|l|}{ Tumor grade } \\
\hline III vs. I/II & 1.18 & $0.70-1.99$ & 0.53 & 1.47 & $0.77-2.80$ & 0.24 \\
\hline \multicolumn{7}{|l|}{ Tumor size } \\
\hline$>2 \mathrm{~cm}$ vs. $\leq 2 \mathrm{~cm}$ & 1.52 & $0.97-2.38$ & 0.07 & 2.26 & $1.17-4.40$ & 0.017 \\
\hline \multicolumn{7}{|l|}{ Adjuvant chemotherapy } \\
\hline C vs. no therapy & 0.91 & $0.42-1.97$ & 0.81 & 1.63 & $0.55-4.85$ & 0.38 \\
\hline E vs. no therapy & 1.14 & $0.47-2.80$ & 0.77 & 1.71 & $0.47-6.25$ & 0.42 \\
\hline C + E vs. no therapy & 1.63 & $0.69-3.85$ & 0.26 & 2.00 & $0.56-7.16$ & 0.29 \\
\hline \multicolumn{7}{|l|}{ Lymph node status } \\
\hline Positive vs. Negative & 3.56 & $2.35-5.38$ & $<0.001$ & 4.09 & $2.35-7.10$ & $<0.001$ \\
\hline \multicolumn{7}{|l|}{ RECQL mRNA expression } \\
\hline Low vs. High & 3.04 & $1.89-4.87$ & $<0.001$ & 4.25 & $2.12-8.46$ & $<0.001$ \\
\hline
\end{tabular}

Abbreviations: DRFS, distant recurrence-free survival; DSS, disease-specific survival; $\mathrm{HR}$, hazard ratio; Cl, confidence interval; ER, estrogen receptor; PR, progesterone receptor; HER2, human epidermal growth factor receptor-2; $C$,chemotherapy; $E$, endocrinotherapy; $C+E$, chemotherapy and endocrinotherapy 
98 months (range 2 to 129 months) in cohort 2. The 10 -year DRFS and DSS rates in the entire study population $(n=322)$ were $77.3 \%$ (95\% CI: $72.4-82.2 \%)$, and 86.4\% (95\% CI: 82.5-90.3\%), respectively. Compared with patients $(n=189)$ with high RECQL protein expression in tumors, patients $(n=133)$ with the low level of RECQL protein expression in tumors had worse DRFS (10-DRFS: $81.5 \%$ vs. $87.5 \%, P=0.024$ ), but no significant difference in DSS (10-DSS: $90.1 \%$ vs. 92.3\%, $P=0.23$ ) in univariate analysis (Fig. 3a-b). Moreover, a multivariable analysis revealed that the low level of RECQL protein expression was an independent unfavorable factor for DRFS (adjusted HR: 2.12, 95\% CI, 1.16-3.88; $P=0.015)$ in these 322 patients after adjustment for age of diagnosis, lymph node status, PR status, ER status, HER2 status, tumor size and adjuvant therapy (Table 4).

\section{Discussion}

In this study, we investigated the association between RECQL expression level and survival in patients with breast cancer. We found that breast cancer patients with low RECQL expression had a worse survival than those with high level. This finding was replicated in mRNA

a

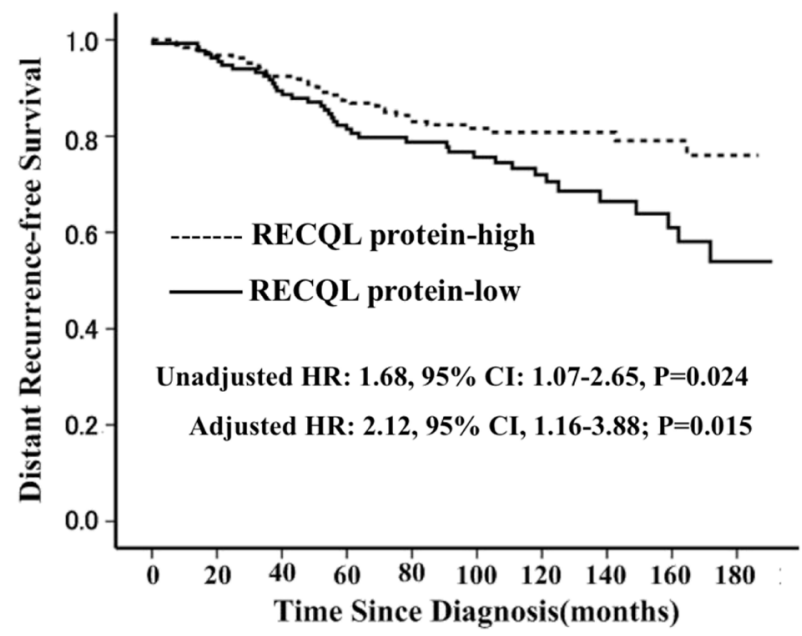

No. at risk

RECQL protein-high RECQL protein-low

$\begin{array}{llllllllll}189 & 178 & 168 & 156 & 126 & 106 & 82 & 53 & 32 & 9\end{array}$

$\begin{array}{lllllllllll}133 & 127 & 115 & 102 & 80 & 68 & 52 & 30 & 21 & 4\end{array}$

b

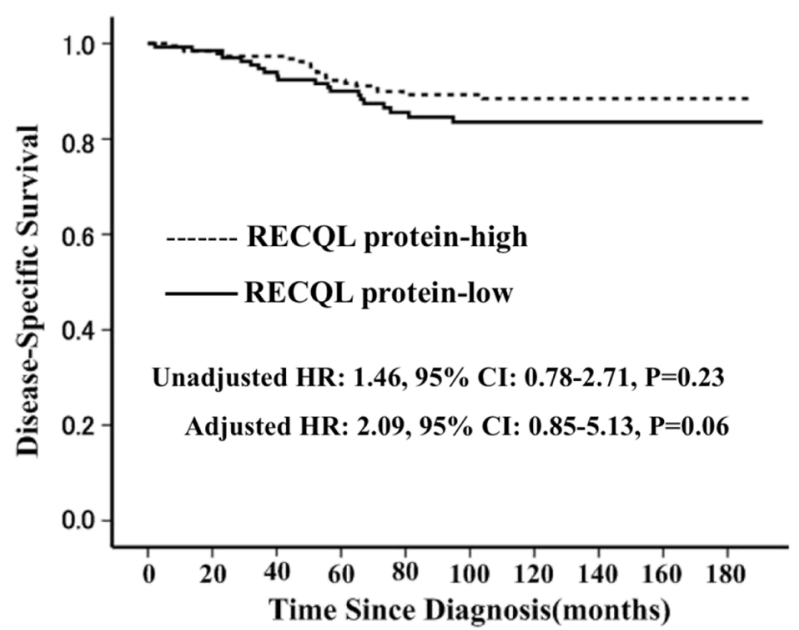

No. at risk

RECQL protein-high

RECQL protein-low

$\begin{array}{cccccccccc}189 & 184 & 178 & 166 & 133 & 112 & 86 & 54 & 35 & 11 \\ 133 & 131 & 122 & 113 & 87 & 74 & 57 & 35 & 26 & 9\end{array}$

Fig. 3 Comparison of the prognosis between RECQL protein expression high and low patients in the second cohort ( $n=332$ ) using Kaplan-Meier method. There was significant difference in distant recurrence-free survival (a) and disease-specific survival (b) between RECQL protein expression high and low patients 
Table 4 Multivariate Analyses of Survival in the Second Study Population ( $\mathrm{N}=322)$

\begin{tabular}{|c|c|c|c|c|c|c|}
\hline \multirow[t]{2}{*}{ Variable } & \multicolumn{3}{|c|}{ DDFS } & \multicolumn{3}{|l|}{ DSS } \\
\hline & $\mathrm{HR}$ & $95 \% \mathrm{Cl}$ & $P$ & $\mathrm{HR}$ & $95 \% \mathrm{Cl}$ & $P$ \\
\hline \multicolumn{7}{|l|}{ Age } \\
\hline$>50 \mathrm{yr}$. vs. $\leq 50 \mathrm{yr}$ & 0.56 & $0.29-1.07$ & 0.08 & 0.34 & $0.13-0.92$ & 0.033 \\
\hline \multicolumn{7}{|l|}{ ER status } \\
\hline Negative vs. Positive & 1.01 & $0.49-2.06$ & 0.99 & 0.58 & $0.19-1.75$ & 0.33 \\
\hline \multicolumn{7}{|l|}{ PR status } \\
\hline Negative vs. Positive & 0.82 & $0.39-1.72$ & 0.60 & 0.86 & $0.30-2.50$ & 0.79 \\
\hline \multicolumn{7}{|l|}{ HER2 status } \\
\hline Positive vs. Negative & 1.72 & $0.80-3.73$ & 0.17 & 4.23 & $1.60-11.46$ & 0.004 \\
\hline \multicolumn{7}{|l|}{ Tumor size } \\
\hline$>2 \mathrm{~cm}$ vs. $\leq 2 \mathrm{~cm}$ & 0.76 & $0.40-1.42$ & 0.39 & 1.01 & $0.41-2.50$ & 0.98 \\
\hline \multicolumn{7}{|l|}{ Lymph node status } \\
\hline Positive vs. Negative & 2.68 & $1.43-5.03$ & 0.002 & 3.68 & $1.39-9.75$ & 0.009 \\
\hline \multicolumn{7}{|l|}{ Adjuvant chemotherapy } \\
\hline C vs. no therapy & 1.71 & $0.38-7.79$ & 0.49 & 1.46 & $0.29-7.29$ & 0.64 \\
\hline E vs. no therapy & 2.53 & $0.44-14.62$ & 0.30 & 1.67 & $0.20-13.69$ & 0.63 \\
\hline C + E vs.no therapy & 2.11 & $0.47-9.47$ & 0.33 & 0.92 & $0.17-5.01$ & 0.63 \\
\hline \multicolumn{7}{|l|}{ RECQL protein expression } \\
\hline Low vs. High & 2.12 & $1.16-3.88$ & 0.015 & 2.09 & $0.85-5.13$ & 0.06 \\
\hline
\end{tabular}

Abbreviations: RFS, recurrence-free survival; DRFS, distant recurrence-free survival; DSS, disease-specific survival; $\mathrm{HR}$, hazard ratio; $\mathrm{Cl}$, confidence interval; ER, estrogen receptor; $P R$, progesterone receptor; HER2, human epidermal growth factor receptor-2;C,chemotherapy; $E$, endocrinotherapy; $C+E$, chemotherapy and endocrinotherapy

and protein level in two independent cohorts, respectively. In cohort $1(N=774)$, patients with low expression level of RECQL mRNA had significantly poorer DRFS and DSS than those with the high level of RECQL expression. In order to further validate this finding in protein level, we analyzed RECQL protein expression in an independent cohort $(N=322)$. In the second cohort, patients with low protein level of RECQL also had lower DRFS than did patients with high level.

The RECQ DNA helicase family has five members, namely WRN, BLM, RECQL, RECQL4, and RECQL5. The biological functions of RECQ DNA helicases are inconsistence between members and they have different expression levels in the same tumor [24]. RECQL is the smallest and most abundant human RecQ helicase, and plays an important role in DNA repair and maintaining replication fork progression [25]. One study showed that RECQL deficiency could lead to chromosomal instability [15]. Recent studies reported that RECQL was a moderate breast cancer susceptibility gene [16-18, 26]. About prognostic studies, there was only one study evaluating the correlation of RECQL expression and survival in breast cancer from England population. Aroraet et al. reported that the low level of RECQL expression was associated with poorer survival than did those with high level expression [27]. By extending their findings, we could demonstrate that RECQL expression was strongly associated with worse DRFS and DSS in Chinese women with breast cancer. Moreover, RECQL expression remained an independent unfavorable factor after adjusting age of diagnosis, ER status, PR status, HER2 status, grade, tumor size, lymph node and adjuvant therapy. In addition, low RECQL expression was also associated with tumor grade III, lymph node-positive, HER2-positive, ER-negative, and tended to Luminal B (HER2+) subtype. These indicated that RECQL may associate with malignant phenotype in breast cancer.

However, some previous studies reported that patients with high level of RECQL expression tend to have a poorer prognosis than patients with low expression in multiple myeloma or epithelial ovarian cancer [28, 29]. Those findings were inconsistent with the results of breast cancer in this study. RECQL is the most expressive member of RecQ helicases and involves in DNA replication [5, 6], DNA repair and stability. RECQL has different expression level in different tumors. Highly proliferative cancer cells would probably need more RECQL for DNA replication and survival. RECQL was overexpressed in multiple myeloma and ovarian cells [28, 29], but RECQL expression was similar in breast cancer cell (MCF 7) relative to normal cells $[30,31]$. Therefore, for these highly 
proliferative cancers, high level of RECQL expression is a bad secondary phenotype.

Some in vitro functional studies showed that RECQL-deficient tumor cells were more sensitive to DNA-toxic drugs [32, 33]. Another study showed that RECQL-overexpression in myeloma cells were resistant to melphalan and bortezomib, whereas silencing RECQL expression can make cells more sensitive to these two drugs [28]. We also analyzed 487 breast cancer patients who received neoadjuvant chemotherapy from the cohort 1 . Among them, 18.9\% (92/487) of patients achieved pathological complete remission (pCR). The result showed that there was no significant association between RECQL mRNA expression and the efficacy of neoadjuvant chemotherapy in breast cancers (data not shown).

The underlying mechanism of RECQL expression affect breast cancer prognosis was not yet clear. Several studies have showed that RECQL played an important role in maintaining genomic stability $[3,4]$. When the expression of RECQL is insufficient, RECQL maybe not play its normal role in maintaining genomic stability, which makes the tumor cells more likely to undergo malignant transformation, and ultimately lead to poor prognosis of breast cancer. Further functional studies are needed to clarify the underlying mechanism.

There are also some limitations in this study. RECQL mRNA and protein were not assayed in the same samples, so the consistency of the mRNA and protein expression level can't be evaluated.

\section{Conclusions}

In summary, in this study we found that the low RECQL expression is strongly associated with poor prognosis in breast cancer. RECQL expression may be a useful marker in estimating the prognosis of breast cancer patients. Nevertheless, further functional and independent studies are warranted to confirm our findings.

\section{Additional file}

Additional file 1: Figure S1. Comparison of the prognosis between RECQL mRNA expression high and low patients in (A) luminal A, (B) luminal B (HER2-), (C) luminal B (HER2+), (D) triple negative, and (E)HER2(+)subtype using Kaplan-Meier method. Comments: luminal A: ER + or PR $\geq 20 \%$, HER2-, Ki-67 < 14\%; luminal B (HER2-): ER+ and HER2-, Ki$67 \geq 14 \%$ or PR- $/<20 \%$, luminal B (HER2+): ER+ and HER2+;HER2(+): ERand PR-, HER2+; TN (triple negative): ER- and PR-, HER2-. (DOCX 502 kb)

\section{Abbreviations}

Cl: Confidence interval; DRFS: Distant recurrence-free survival; DSS: Diseasespecific survival; ER: Estrogen receptor; HER2: Human epidermal growth factor receptor-2; HR: Hazard ratio; IHC: Immunohistochemical; PCR: Polymerase chain reaction; PR: Progesterone receptor; TNM: Tumor node metastasis

\section{Funding}

This study was supported by the 973 project 2013CB911004; and grants from the National Natural Science Foundation of China (No. 81071629). The funders had no role in study design, data collection and analysis, decision to publish, or preparation of the manuscript.

\section{Availability of data and materials}

The datasets used and/or analyzed during the current study are available from the corresponding author on reasonable request.

\section{Authors' contributions}

Conceived and designed the experiments: YX. Performed the experiments: $H X$. Analyzed the data: HX, YX. Contributed reagents/materials/analysis tools: TO, JL, TW, ZF, TF, BL. Wrote the paper: YX, YX. All authors read and approved the final manuscript.

\section{Ethics approval and consent to participate}

This study was conducted in accordance with the ethics principles of the Declaration of Helsinki and approved by the Research and Ethics Committee of Peking University Cancer Hospital. All patients were written informed consent.

Consent for publication

Not applicable.

\section{Competing interests}

The authors declare that they have no competing interest.

\section{Publisher's Note}

Springer Nature remains neutral with regard to jurisdictional claims in published maps and institutional affiliations.

Received: 3 January 2018 Accepted: 12 June 2018

Published online: 18 June 2018

References

1. Siegel RL, Miller KD, Jemal A. Cancer statistics, 2017. CA Cancer J Clin. 2017; 67(1):7-30.

2. Koren S, Bentires-Alj M. Breast tumor heterogeneity: source of fitness, hurdle for therapy. Mol Cell. 2015;60(4):537-46.

3. Chu WK, Hickson ID. RecQ helicases: multifunctional genome caretakers. Nat Rev Cancer. 2009;9(9):644-54.

4. Croteau DL, Popuri V, Opresko PL, Bohr VA. Human RecQ helicases in DNA repair, recombination, and replication. Annu Rev Biochem. 2014;83:519-52.

5. Seki M, Miyazawa H, Tada S, Yanagisawa J, Yamaoka T, Hoshino S, Ozawa K, Eki T, Nogami M, Okumura K, et al. Molecular cloning of CDNA encoding human DNA helicase Q1 which has homology to Escherichia coli rec Q helicase and localization of the gene at chromosome 12p12. Nucleic Acids Res. 1994;22(22):4566-73.

6. Thangavel S, Mendoza-Maldonado R, Tissino E, Sidorova JM, Yin J, Wang W, Monnat RJ, Jr., Falaschi A, Vindigni A: Human RECQ1 and RECQ4 helicases play distinct roles in DNA replication initiation. Mol Cell Biol 2010, 30(6):1382-1396.

7. Contreras-Levicoy J, Moreira-Ramos S, Rojas DA, Urbina F, Maldonado E. Transcription directed by human core promoters with a HomolD box sequence requires DDB1, RECQL and RNA polymerase II machinery. Gene. 2012;505(2):318-23.

8. LeRoy G, Carroll R, Kyin S, Seki M, Cole MD. Identification of RecQL1 as a Holliday junction processing enzyme in human cell lines. Nucleic Acids Res. 2005;33(19):6251-7.

9. Parvathaneni S, Stortchevoi A, Sommers JA, Brosh RM Jr, Sharma S. Human RECQ1 interacts with Ku70/80 and modulates DNA end-joining of doublestrand breaks. PLoS One. 2013;8(5):e62481.

10. Sharma S, Brosh RM Jr. Human RECQ1 is a DNA damage responsive protein required for genotoxic stress resistance and suppression of sister chromatid exchanges. PLoS One. 2007;2(12):e1297.

11. Lu X, Parvathaneni S, Hara T, Lal A, Sharma S. Replication stress induces specific enrichment of RECQ1 at common fragile sites FRA3B and FRA16D. Mol Cancer. 2013;12(1):29.

12. Berti M, Ray Chaudhuri A, Thangavel S, Gomathinayagam S, Kenig S, Vujanovic M, Odreman F, Glatter T, Graziano S, Mendoza-Maldonado R, et al. 
Human RECQ1 promotes restart of replication forks reversed by DNA topoisomerase I inhibition. Nat Struct Mol Biol. 2013;20(3):347-54.

13. Popuri V, Croteau DL, Brosh RM, Jr., Bohr VA: RECQ1 is required for cellular resistance to replication stress and catalyzes strand exchange on stalled replication fork structures. Cell cycle (Georgetown, Tex) 2012, 11(22):4252-4265.

14. Popuri V. Hsu J, Khadka P. Horvath K, Liu Y, Croteau DL, Bohr VA. Human RECQL1 participates in telomere maintenance. Nucleic Acids Res. 2014;42(9):5671-88.

15. Sharma S, Stumpo DJ, Balajee AS, Bock CB, Lansdorp PM, Brosh RM Jr, Blackshear PJ. RECQL, a member of the RecQ family of DNA helicases, suppresses chromosomal instability. Mol Cell Biol. 2007;27(5):1784-94.

16. Sun J, Wang Y, Xia Y, Xu Y, Ouyang T, Li J, Wang T, Fan Z, Fan T, Lin B, et al. Mutations in RECQL gene are associated with predisposition to breast Cancer. PLoS Genet. 2015;11(5):e1005228.

17. Cybulski C, Carrot-Zhang J, Kluzniak W, Rivera B, Kashyap A, Wokolorczyk D, Giroux S, Nadaf J, Hamel N, Zhang S, et al. Germline RECQL mutations are associated with breast cancer susceptibility. Nat Genet. 2015;47(6):643-6.

18. Kwong A, Shin VY, Cheuk IW, Chen J, Au CH, Ho DN, Chan TL, Ma ES, Akbari MR, Narod SA. Germline RECQL mutations in high risk Chinese breast cancer patients. Breast Cancer Res Treat. 2016;157(2):211-5.

19. Li D, Frazier M, Evans DB, Hess KR, Crane CH, Jiao L, Abbruzzese JL. Single nucleotide polymorphisms of RecQ1, RAD54L, and ATM genes are associated with reduced survival of pancreatic cancer. Journal of clinical oncology : official journal of the American Society of Clinical Oncology. 2006;24(11):1720-8.

20. Li D, Moughan J, Crane C, Hoffman JP, Regine WF, Abrams RA, Safran H, Liu C, Chang P, Freedman GM, et al. RECQ1 A159C polymorphism is associated with overall survival of patients with resected pancreatic Cancer: a replication study in NRG oncology radiation therapy oncology group 9704 . Int J Radiat Oncol Biol Phys. 2016;94(3):554-60.

21. Yuan H, Chen J, Liu Y, Ouyang T, Li J, Wang T, Fan Z, Fan T, Lin B, Xie Y, Association of PIK3CA mutation status before and after neoadjuvant chemotherapy with response to chemotherapy in women with breast Cancer. Clinical cancer research : an official journal of the American Association for Cancer Research. 2015;21(19):4365-72.

22. Han X, Diao L, Xu Y, Xue W, Ouyang T, Li J, Wang T, Fan Z, Fan T, Lin B, et al. Association between the HER2 lle655Val polymorphism and response to trastuzumab in women with operable primary breast cancer. Ann Oncol. 2014;25(6):1158-64.

23. Xu Y, Ouyang T, Li J, Wang T, Fan Z, Fan T, Lin B, Xie Y. Predictive value of BRCA1/2 mRNA expression for response to neoadjuvant chemotherapy in BRCA-negative breast cancers. Cancer Sci. 2018;109(1):166-73.

24. Lao W, Welcsh P, Luo Y, Carter KT, Dzieciatkowski S, Dintzis S, Meza J, Sarvetnick NE, Monnat RJ Jr, Loeb LA, et al. Altered RECQ helicase expression in sporadic primary colorectal cancers. Transl Oncol. 2013;6(4):458-69.

25. Sharma S, Brosh RM Jr. Unique and important consequences of RECQ1 deficiency in mammalian cells. Cell cycle (Georgetown, Tex). 2008;7(8):989-1000.

26. Akbari MR, Cybulski C. RECQL: a DNA helicase in breast cancer. Oncotarget 2015;6(29):26558-9.

27. Arora A, Parvathaneni S, Aleskandarany MA, Agarwal D, Ali R, Abdel-Fatah T, Green AR, Ball GR, Rakha EA, Ellis IO, et al. Clinicopathological and functional significance of RECQL1 helicase in sporadic breast cancers. Mol Cancer Ther. 2017;16(1):239-50.

28. Viziteu E, Klein B, Basbous J, Lin YL, Hirtz C, Gourzones C, Tiers L, Bruyer A Vincent L. RECQ1 helicase is involved in replication stress survival and drug resistance in multiple myeloma. Leukemia. 2017:31(10):2104-13.

29. Matsushita Y, Yokoyama Y, Yoshida H, Osawa Y, Mizunuma M, Shigeto T, Futagami M, Imaizumi T, Mizunuma $\mathrm{H}$. The level of RECQL1 expression is a prognostic factor for epithelial ovarian cancer. Journal of ovarian research. 2014;7:107.

30. Futami K, Kumagai E, Makino H, Goto H, Takagi M, Shimamoto A, Furuichi Y Induction of mitotic cell death in cancer cells by small interference RNA suppressing the expression of RecQL1 helicase. Cancer Sci. 2008:99(1):71-80.

31. Arai A, Chano T, Futami K, Furuichi $Y$, Ikebuchi $K$, Inui $T$, Tameno $H$, Ochi $Y$, Shimada T, Hisa Y, et al. RECQL1 and WRN proteins are potential therapeutic targets in head and neck squamous cell carcinoma. Cancer Res. 2011;71(13):4598-607.

32. Sharma S, Phatak P, Stortchevoi A, Jasin M, Larocque JR. RECQ1 plays a distinct role in cellular response to oxidative DNA damage. DNA repair. 2012;11(6):537-49.

33. Wu Y, Brosh RM, Jr.: Distinct roles of RECQ1 in the maintenance of genomic stability. DNA repair 2010, 9(3):315-324.

\section{Ready to submit your research? Choose BMC and benefit from:}

- fast, convenient online submission

- thorough peer review by experienced researchers in your field

- rapid publication on acceptance

- support for research data, including large and complex data types

- gold Open Access which fosters wider collaboration and increased citations

- maximum visibility for your research: over $100 \mathrm{M}$ website views per year

At BMC, research is always in progress.

Learn more biomedcentral.com/submissions 